\title{
Діабетична мікроангіопатія у хворих із цукровим діабетом та хронічною критичною ішемією нижньої кінцівки
}

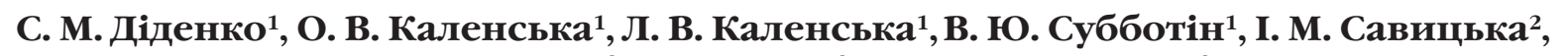 \\ Ю. М. Гупало, О. Є. Швед ${ }^{3}$, Д. Ю. Шаповалов ${ }^{3}$
}

${ }^{1}$ Клінічна лікарня «Феофанія», м. Київ,

${ }^{2}$ Національний інститут хірургії та трансплантології імені О. О. Шалімова НАмН України, м. Київ,

${ }^{3}$ Науково-практичний центр профілактичної та клінічної медицини, м. Київ

\section{Diabetic microangiopathy in the patients, suffering diabetes mellitus and chronic critical ischemia of lower extremity}

\author{
S. M. Didenko ${ }^{1}$, O. V. Kalenska ${ }^{1}$, L. V. Kalenska ${ }^{1}$, V. U. Subbotin ${ }^{1}$, I. M. Savytska ${ }^{2}$, \\ Yu. M. Hupalo ${ }^{3}$, O. E. Shved ${ }^{3}$, D. Yu. Shapovalov ${ }^{3}$ \\ ${ }^{1}$ Clinical Hospital «Feofania», Kyiv, \\ ${ }^{2}$ Shalimov National Institute of Surgery and Transplantology, Kyiv, \\ ${ }^{3}$ Scientific-Practical Centre of Prophylactic and Clinical Medicine, Kyiv
}

Реферат

Мета. Дослідити кількісні характеристики ураження судин гемомікроциркуляторного русла (ГМЦР) шкіри у хворих із цукровим діабетом (ЦЛ) та хронічною критичною ішемією нижньої кінцівки (ХКІНК) і з’ясувати можливість їх використання в клінічній практиці.

Матеріали і методи. Для імуногістохімічного та гістологічного дослідження із 165 парафінових блоків шкіри, підшкірної клітковини і м'язів 49 хворих із ЦД та ХКІНК було виготовлено 414 мікропрепаратів. Вік паціентів коливався від 56 до 88 років, середній вік становив $(67,9 \pm 8,1)$ року. Чоловіків було 28 (57,1\%), жінок - 21 (42,9\%). Хворих лікували в Центрі судинної хірургі Клінічної лікарні «Феофанія» Державного управління справами в 2013 - 2016 рр. Для порівняння були відібрані зразки шкіри та м'язів 20 паціентів, які не мали системних захворювань (контрольна група). Частину препаратів (62,1\%) забарвлювали гематоксиліном і еозином, пікрофуксином за ван Гізоном. Імуногістохімічні реакції (37,9\% препаратів) проводили за стандартними протоколами з використанням моноклональних мишачих та кролячих антитіл.

Результати. Виявлені характерні зміни морфометричних показників судин ГМЦР шкіри хворих з ЦД та ХКІНК. Розроблено методику розрахунку показника ступеня (ПС) діабетичної мікроангіопатії (ДМАП). Виявлена кореляція між ступенем ДМАП та ймовірністю виникнення тромбозу після гібридної артеріальної реконструкції.

Висновки. Внутрішній діаметр судин ГМЦР шкіри хворих з ДМАП 3-ГО ступеня зменшувався: артеріол - у середньому в 2,6 разу; венул - у 3,1 разу, капілярів - на 43\%. Протягом періоду спостереження на тлі антитромбоцитарної терапії при ДМАП 1-го ступеня тромбозу зони артеріальної реконструкції у хворих не фіксували, при ДМАП 2-го ступеня тромбоз зони артеріальної реконструкції зафіксували у 1 (9,1\%) 311 хворих, при ДМАП 3-го ступеня - у 7 (22,6\%) 331 хворого. Проведеним клініко-морфологічним дослідженням виявлені зміни ГМЦР шкіри хворих із ЦД та ХКІНК, використання яких дає змогу конкретизувати лікувальну тактику. Отримані результати свідчать про важливу роль ДМАП у створенні периферичного судинного опору та необхідність враховувати ПС ДМАП для призначення обстеження та проведення лікування після артеріальної реконструкції хворим із ЦД та ХКІНК.

Ключові слова: цукровий діабет; гемомікроциркуляторне русло; діабетична мікроангіопатія; ішемія; гібридна артеріальна реконструкція.

\section{Abstract}

Objective. To investigate quantitative characteristics of the vessels affection in hemomicrocirculatory bed (HMCB) of the skin in patients, suffering diabetes mellitus (DM) and chronic critical ischemia of the lower extremity (HCILE), and to reveal a possibility of their application in clinical practice.

Materials and methods. There were done 414 micropreparations for immunohistochemical and histological investigation of 165 paraffin blocks, consisting of the skin, subcutaneous cellular tissue and muscles material, obtained in 49 patients with DM and HCILE. The patients were 56 - 88 yrs old, average age have constituted $(67.9 \pm 8.1)$ yrs. There were $28(57.1 \%)$ men, and $21(42.9 \%)$ women. The patients were treated in the Vascular Surgery Centre of Clinical hospital «Feofania» of the State administration management in 2013 -2016 yrs. The skin and muscle probes were taken in 20 patients, who did not owe systemic diseases (control group), for comparative studies. The part of preparations (62.1\%) were dyed by hematoxilin and eosin, picrofuxin in accordance to van Gizon procedure. Immunohistochemical reactions (37.9\% of the preparations) were conducted in accordance to standard protocols, using monoclonal mouse and rabbit's antibodies.

Results. Characteristic changes of morphometric indices of the cutaneous HMCB in patients, suffering DM and HCILE, were registered. The procedure of calculation was elaborated of the degree index (DI) for diabetic microangiopathy (DMAP). Correlation between the DMAP degree and possibility of thrombosis occurrence after the hybrid arterial reconstruction was revealed.

Conclusion. Internal diameter of cutaneous vessels in the patients, suffering the third degree DMAP, have reduced significantly: for arteriolas - at average in 2.6 times; venulas - in 3.1 times, and capillaries - by $43 \%$. During the observation period on background of antithrombocytic therapy in patients with DMAP of the first degree the cases of thrombosis of the arterial reconstruction zone were not registered, and in DMAP of the second degree the arterial reconstruction zone thrombosis was registered in 1 (9.1\%) of 11 patients, while in DMAP of the third degree - in 7 (22.6\%) of 31 patients. Exposure of changes in HMCB of the skin, using clinico-morphological investigation, in patients with DM and HCILE permits to formulate the treatment tactics. The results obtained witness a significant role of DMAP in creation of peripheral vascular resistance and necessity to take into account a DI of DMAP while prescribing examination and conduction of treatment after arterial reconstruction in patients with DM and HCILE.

Keywords: diabetes mellitus; hemomicrocirculatory bed; diabetic microangiopathy; ischemia; hybrid arterial reconstruction. 
За даними Міжнародної діабетичної федерації серед дорослого населення в 2015 р. хворих із Цд було близько 250 мільйонів, більше того, простежується чітка тенденція до неухильного зростання кількості хворих із ЦД у майбутньому [1]. До моменту встановлення діагнозу ЦД більше половини цих хворих уже мають ДМАП [2]. У понад 70\% хворих із Цд розвиваються ускладнення, в тому числі синдром діабетичної стопи (СДС) - складний комплекс анатомо-функціональних змін у тканинах на тлі діабетичної мікро- і макроангіопатії, нейропатії та остеоартропатії [3].

Особливо складних тактичних і технічних рішень потребують хворі з ішемічною формою (ІФ) СДС у поєднанні зі стенотично-оклюзійним ураженням (СОУ) поверхневої стегнової артерії (ПСА) та артерій підколінно-гомілково-стопового сегмента, у яких застосування стандартних методів артеріальних реконструкцій не завжди ефективне [4].

Велику увагу дослідники приділяють патогенетичній ролі морфологічних змін судин ГМЦР у розвитку ускладнень ЦД, зокрема СДС. Незважаючи на очевидність зв'язку між судинними порушеннями і станом шкіри хворих із ЦД, а також наявність численних даних про кореляцію між ними, здатність судинних порушень самостійно призводити до некрозу тканин стопи не доведена, попри те що факт порушення тонусу мікросудин при ЦД не викликає сумнівів [5].

Мета дослідження: визначити кількісні характеристики ураження судин ГМЦР шкіри хворих із ЦД та ХКІНК і з'ясувати можливість їх використання в клінічній практиці.

\section{Матеріали і методи дослідження}

Для імуногістохімічного та гістологічного дослідження із 165 парафінових блоків шкіри, підшкірної клітковини і м'язів 49 хворих із ЏД виготовлено 414 мікропрепаратів. Всі пацієнти мали ХКІНК з виразково-некротичним ураженням стопи на тлі поєднаного СОУ ПСА та підколінногомілково-стопового сегмента, їм виконані гібридні реваскуляризуючі оперативні втручання на артеріях нижньої кінцівки. Вік пацієнтів коливався від 56 до 88 років, середній вік становив $(67,9 \pm 8,1)$ року. Чоловіків було 28

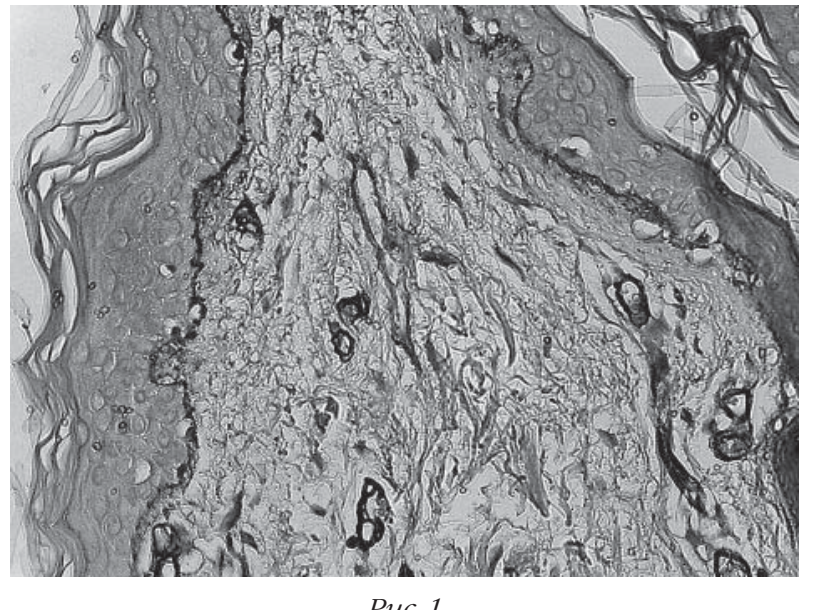

Розпушення та потовщення базальних мембран судин ГМЦР сосочкового шару шкіри.

Забарвлення антитілами до колагену IV типу. 3б. ×400.
(57,1\%), жінок - 21 (42,9\%). Хворіли на џД більше 10 років 33 (67,3\%) пацієнти. Під час госпіталізації у 30 (61,2\%) пацієнтів Цд мав декомпенсований характер. Хворих лікували в Центрі судинної хірургії Клінічної лікарні «Феофанія» в 2013 - 2016 рр. Для порівняння були відібрані зразки шкіри та м'язів 20 пацієнтів, які не мали системних захворювань (контрольна група). У хворих з ЦД матеріал отримували під час виконання гібридних артеріальних реконструкцій, які полягали у відкритому хірургічному втручанні на стегновій артерії у вигляді шунтування або ендартеректомії і ендоваскулярному втручанні на артеріях підколінно-гомілкового сегмента, у хворих контрольної групи - під час загально-хірургічних і ортопедичних операцій 3 дотриманням правил етики і деонтології.

Частину препаратів (62,1\%) забарвлювали гематоксиліном і еозином, пікрофуксином за ван Гізоном. Імуногістохімічні реакції (37,9\% препаратів) проводили за стандартними протоколами з використанням моноклональних мишачих та кролячих антитіл [6].

Проводили імуногістохімічні дослідження з використаннням таких антигенів: VEGF - судинний ендотеліальний фактор росту; CD31- ендотеліальний фактор (маркер ендотеліальних клітин); гладком'язовий актин маркер доброякісного судинного процесу, також виявляє клітини з частковим гладком'язовим диференціюванням; колаген IV типу - маркер судинного процесу, виявляють у базальних мембранах [7].

Морфометричну та статистичну обробку здійснювали за допомогою комп'ютерної програми "Рaradise". Статистичну достовірність різниці визначали за допомогою t-критерію Ст'юдента [8]. Для всіх статистичних даних визначено рівень достовірності менше 0,05 ( $\mathrm{p}<0,05)$.

\section{Результати}

У зразках шкіри хворих з ЦД у разі збільшення експресії колагену IV типу спостерігали потовщення базальних мембран епідермісу в середньому в 2,7 разу та кровоносних судин у 3,1 разу, що призводило до прогресування звуження судин. Виявляли також розпушення базальної мембрани стінки судин ГМЦР сосочкового шару шкіри

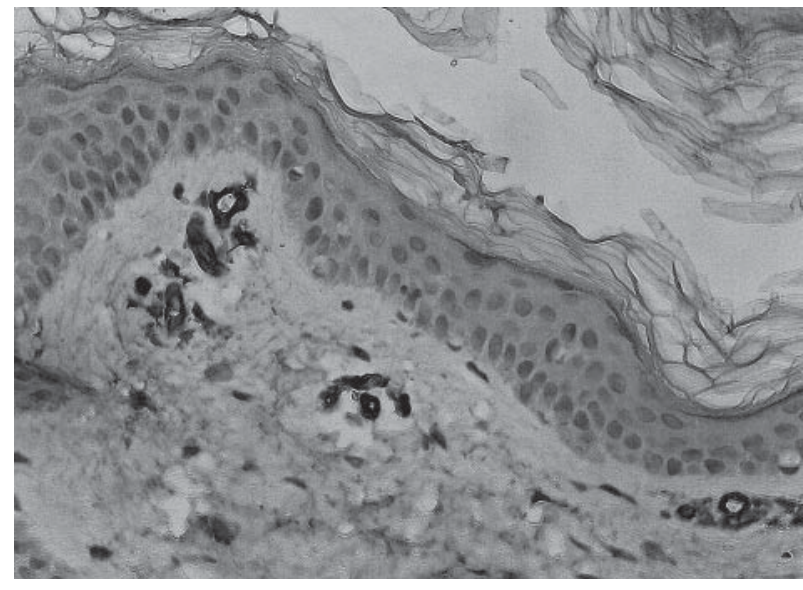

Puc. 2.

Вогнищева експресія CD31у судинах дерми. Імуногістохімічне забарвлення антитілами до СD31. 3б. ×400. 


\begin{tabular}{|c|c|c|c|c|}
\hline Таблиця 1. & етрів судин ГML & ового шару & & \\
\hline \multirow{2}{*}{ Параметри } & \multirow{2}{*}{ Контрольна група } & \multicolumn{3}{|c|}{ Хворі з ДМАП } \\
\hline & & 1-го ступеня & 2-го ступеня & 3-го ступеня \\
\hline \multicolumn{5}{|l|}{ Діаметр просвіту судин, мкм } \\
\hline артеріоли & $26,63 \pm 1,69$ & $24,02 \pm 2,7^{*}$ & $15,65 \pm 1,44^{*}$ & $10,28 \pm 0,95^{*}$ \\
\hline венули & $38,98 \pm 2,15$ & $33,26 \pm 3,07$ & $20,18 \pm 2,03 *$ & $12,64 \pm 1,06^{*}$ \\
\hline капіляри & $8,19 \pm 0,69$ & $7,58 \pm 1,1^{*}$ & $6,38 \pm 0,58 *$ & $5,73 \pm 0,47^{*}$ \\
\hline Кількість капілярів на 1 мм² & $98,5 \pm 3,4$ & $112,1 \pm 5,6$ & $138,3 \pm 4,1^{*}$ & $156,9 \pm 8,1^{*}$ \\
\hline
\end{tabular}

\begin{tabular}{|c|c|c|c|c|}
\hline \multirow{2}{*}{ Параметри } & \multicolumn{4}{|c|}{ Кількість балів } \\
\hline & 0 & 1 & 2 & 3 \\
\hline \multicolumn{5}{|l|}{ Діаметр просвіту судин, мкм } \\
\hline артеріоли & 26 і більше & $25-18$ & $17-12$ & 11 і менше \\
\hline венули & 39 і більше & $38-25$ & $24-14$ & 14 і менше \\
\hline капіляри & 8,2 і більше & $8,1-6,5$ & $6,4-5,5$ & 5,4 і менше \\
\hline Кількість капілярів на 1 мм² & 98 і менше & $99-128$ & $129-157$ & 158 і більше \\
\hline
\end{tabular}

(рис. 1), що порушувало їх проникність. Товщина базальної мембрани капілярів при 1-му ступені ДМАП становила $(2,01 \pm 0,05)$ мкм $(\mathrm{n}=8)$, при $2-\mathrm{мy}-(2,67 \pm 0,05)$ мкм $(\mathrm{n}=10)$, при 3-му - $(3,89 \pm 0,11)$ мкм $(\mathrm{n}=31)(\mathrm{p}<0,05)$.

Крім того, внутрішній діаметр усіх судин ГМЦР мав тенденцію до зменшення.

У шкірі та м'язах хворих з ІФ СДС виявлено експресію CD31, яка мала високу інтенсивність та вогнищевий характер (рис. 2), на деяких ділянках препаратів експресії CD31 у судинах не було внаслідок атрофії ендотелію, крім того, визначали безсудинні ділянки, частіше - під час дослідження м'язів.

Підрахунок кількості капілярів сосочкового шару дерми на 1 мм² показав, що у хворих з 1-м ступенем ДМАП їх щільність була найменша, але поступово збільшувалась, максимально зростаючи при 3-му ступені ДМАП (табл. 1).

У шкірі хворих із Цд спостерігали зміни процесів ангіогенезу. Новоутворення кровоносних судин збільшувалось у разі підвищення експресії 1 -го рецептора VEGF (VEGFR-1), корелюючи з вираженістю порушень в ГМЦР. Так, у судинах шкіри пацієнтів контрольної групи спостерігали слабо виражену імунопозитивну реакцію, а в судинах пацієнтів з 2-м та 3-м ступенями ДМАП посилювався синтез VEGF і реакція кровоносних судин була яскраво виражена. Про посилення ангіогенезу при 2-му і 3-му ступенях ДМАП свідчила підвищена експресія гладком'язового актину в стінках судин ГМЦР шкіри.

У стінці артерій хворих із 2-м та 3-м ступенями ДМАП спостерігали гіперплазію гладком'язових клітин, в окремих міозитах були включення ліпідів, що вказувало на дистрофічні зміни в цих клітинах. Глибина і прояви дистрофічних і деструктивних процесів у клітинах кровоносних судин наростали зі збільшенням тяжкості стану хворих.

Морфологічна структура шкіри може відображати зміни в інших тканинах. Зважаючи на відносну простоту біопсії шкіри, перспективним є іiі використання для визначення ПС ДМАП.
Базуючись на результатах дослідження, ми розробили методику визначення ПС ДМАП, яка передбачає кількісну оцінку в залежності від діаметра просвіту судин і кіль-

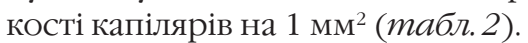

Приклад розрахунку ПС ДМАП для хворого з ІФ СДС: середній діаметр артеріоли 15,28 мкм - 2 бали, середній діаметр венули 27,32 мкм - 1 бал, середній діаметр капіляра 4,96 мкм - 3 бали, середня кількість капілярів на 1

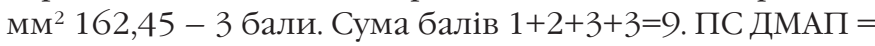
$9 / 4=2,25$.

Вочевидь, що ПС ДМАП може коливатися в межах від 0 до 3. Відповідно при ПС ДМАП у межах 0 - 1 ДМАП вважали легкою, або 1-го ступеня, при ПС ДМАП у межах 1 - 2 - середньої тяжкості, або 2-го ступеня, при ПС ДМАП у межах 2 - 3 - тяжкою, або 3-го ступеня.

Із 49 хворих, препарати шкіри яких були досліджені, у 7 (14,3\%) ПС ДМАП коливався у межах 0 - 1, що свідчило про 1-й ступінь ДМАП, у 11 (22,4\%) - у межах 1 - 2, що свідчило про 2-й ступінь ДМАП, у 31 (63,3\%) - у межах 2 - 3, що свідчило про 3-й ступінь ДМАП. Усі хворі після виконаної гібридної артеріальної реконструкції протягом періоду спостереження отримували антитромбоцитарну терапію препаратом клопідогрель 75 мг перорально 1 раз на добу. У 7 хворих з ДМАП 1-го ступеня протягом періоду спостереження тромбозу зони артеріальної реконструкції не було. 311 хворих з ДМАП 2-го ступеня протягом періоду спостереження тромбоз зони артеріальної реконструкції зафіксовано у 1 (9,1\%), з 31 хворого з ДМАП 3-го ступеня - у 7 (22,6\%).

\section{Обговорення}

У разі виявлення колагену IV типу та ШИК-позитивних сполук у зразках шкіри хворих з ДМАП 3-го ступеня спостерігали дифузне потовщення базальних мембран епідермісу шкіри й кровоносних судин дерми та м'язів, що супроводжувалось зменшенням їх просвіту. Накопичення колагену IV типу призводило до зменшення просвіту су- 
дин ГМЦР, а в деяких спостереженнях - до повної їх облітерації. В умовах ДМАП у шкірі через порушення регенераційної здатності спостерігали зниження швидкості проліферації клітин ендотелію. Внутрішній діаметр судин ГМЦР шкіри у хворих з ДМАП 3-го ступеня зменшувався: артеріол - у середньому у 2,6 разу, венул - у 3,1 разу, капілярів - на 43\%. Дослідженням експресії CD31 у кровоносних судинах хворих з ЦД та ХКІНК виявлено збільшення щільності капілярів у дермі, пошкодження ендотелію судин спостерігали при ДМАП 2-го ступеня, більш значне - при ДМАП 3-го ступеня. Ангіопатія на тлі ЦД характеризувалась прогресуванням дистрофічних та деструктивних процесів переважно в ендотеліальних клітинах та гіпертрофією міозитів медії, про це свідчило підвищення рівня експресії гладком'язового актину. У шкірі нижньої кінцівки хворих з ЏД та ХКІНК у разі виявлення VEGFR-1 спостерігали яскраво виражену експресію, якої не було в контрольних зразках.

Після проведеної гібридної артеріальної реконструкції протягом періоду спостереження на тлі антитромбоцитарної терапії прогресивно зростала частота виникнення тромботичних ускладнень в залежності від ступеня ДМАП. Це свідчить про важливу роль ДМАП у створенні периферичного судинного опору та необхідність враховувати ПС ДМАП для призначення лікування після артеріальних реконструкцій у хворих з ЦД та ІФ СДС.

\section{Висновки}

1. Внутрішній діаметр судин ГМЦР шкіри у хворих 3 ДМАП 3-го ступеня зменшувався: артеріол - у середньому у 2,6 разу; венул - у 3,1 разу, капілярів - на 43\%.

2. Після виконаної гібридної артеріальної реконструкції протягом періоду спостереження на тлі антитромбоцитарної терапії у хворих з ДМАП 1-го ступеня тромбозу не фіксували, із 11 хворих з ДМАП 2-го ступеня тромбоз зони артеріальної реконструкції зафіксовано у 1 (9,1\%), 3 31 хворого з ДМАП 3-го ступеня - у 7 (22,6\%).
3. Проведене клініко-морфологічне дослідження показало наявність змін ГМЦР шкіри хворих з ЦД та ХКІНК, які можуть бути використані для конкретизації лікувальної тактики.

4. Отримані результати свідчать про важливу роль ДМАП у створенні периферичного судинного опору та необхідність враховувати ПС ДМАП для призначення обстеження та лікування після артеріальних реконструкцій хворим з ЦД та ХКІНК.

\section{References}

1. Shah B, Rockman CB, GuoY. Diabetes and vascular disease in different arterial territories. Diabet Care. 2014;37(6):1636-42. doi: 10.2337/ dc13-2432.

2. Fox CS, Golden SH, Anderson C, Bray GA, Burke LE, de Boer IH, et al. Update on prevention of cardiovascular disease in adults with type 2 diabetes mellitus in light of recent evidence: a scientific statement from the american heart association and the american diabetes association. Diabet Care. 2015 Sep;38(9):1777-803. doi: 10.2337/dci15-0012.

3. Rubio JA, Aragón-Sánchez J, Jiménez S. Reducing major lower extremity amputations after the introduction of a multidisciplinary team for the diabetic foot. Int J Low Extrem Wounds. 2014;13(1):22-6. doi: $10.1177 / 1534734614521234$.

4. Nehler MR, Duval S, Diao L. Epidemiology of peripheral arterial disease and critical limb ischemia in an insured national population. J Vasc Surg. 2014;60(3):686-95. doi: 10.1016/j.jvs.2014.03.290.

5. Parodi A, Castello M, Corbetta S, Cordera R, Cristaudo A, Cucchia RG. Skin and diabetes: an experts' opinion from the Italian diabetologists and dermatologists of the DiaDex group. Ital Dermatol Venereol. 2018 Oct;153(5):649-58. doi: 10.23736/S0392-0488.18.06080-7.

6. Petrov SV, Rajhlin NT Rukovodstvo po immunohimicheskoj diagnostike opuholej cheloveka pod redakciej 3 izdanie dopolnennoe i pererabotannoe. Kazan’: Izd-vo «Titul»; 2004; 456 p. [In Russian].

7. Prophet EB, Mills B, Arrington JB, Sobin L. Laboratory methods in histotechnology. institute of pathology. Washington; 1994. 274 p.

8. Avtandilov GG. Meditsinskaya morfometriya. Rukovodstvo. Moskva: Meditsina; 1990. 384 p. [In Russian]. 